\title{
Medical students' risk of infection with bloodborne viruses at home and abroad: questionnaire survey
}

\author{
Claire F Gamester, Anthea J Tilzey, Jangu E Banatvala
}

\section{Editorial by \\ Wilkinson and \\ p 161 \\ Guy's, King's \\ College, and \\ St Thomas's School \\ of Medicine, \\ St Thomas's \\ Campus, London \\ SE1 7EH \\ Claire F Gamester, \\ medical student \\ Anthea J Tilzey, \\ consultant virologist \\ Jangu E Banatvala, \\ professor of clinical \\ virology \\ Correspondence to: \\ Dr Tilzey}

a.gem@umds.ac.uk

BMJ 1999;318:158-60

website

extra

Additional material will be found on our website

www.bmj.com

\begin{abstract}
Objective To determine risks of exposure to and prevention of bloodborne virus infections among medical students during their elective period. Design Questionnaire study of students returning from their electives in 1997-8.

Setting Urban teaching hospital.

Subjects 220 final year medical students.

Results 148 students (67\%) returned questionnaires; all had been vaccinated against hepatitis B. 65 respondents (44\%) had visited areas of relatively high endemicity for HIV, although 27 (42\%) of these, all of whom had visited areas other than sub-Saharan Africa, were unaware of this. All but one had discussed their elective with advisers. Four students experienced percutaneous or mucosal exposure to potentially infectious body fluids, three in areas with a high prevalence of HIV infection. 44 respondents (30\%) had experienced at least one such exposure during their clinical training; $75 \%$ of these exposures were unreported. 34\% (13/38) students who visited areas known to have a high prevalence of HIV infection took with them a starter pack of zidovudine for post-exposure prophylaxis; $53 \%$ (20) took latex gloves and $63 \%$ (24) a medi-kit. None of the 27 students who were unaware that the areas they visited had a relatively high prevalence of HIV infection took zidovudine; only $15 \%$ (4) took gloves and 30\% (8) a medi-kit.

Conclusions Medical schools should produce, regularly update, and implement guidelines regarding protection from bloodborne viruses during clinical studies, including electives. Education and training in infection control should start at the earliest opportunity.
\end{abstract}

\section{Introduction}

Students in medical schools in Britain and in many other countries have an elective period, in which they are encouraged to pursue medical studies abroad. Many go to developing countries, where a natural enthusiasm to be involved in procedures that they might not experience at home, ${ }^{1}$ combined with varying standards of supervision, may place students at risk of bloodborne virus infections such as HIV, hepatitis C, and hepatitis $\mathrm{B}$.

At the United Medical and Dental Schools of Guy's and St Thomas's Trust (UMDS; now Guy's, King's College, and St Thomas's School of Medicine), 18 consultants act as clinical advisers to students. They are responsible for pastoral care, academic guidance, and advice on electives. One consultant virologist and clinical adviser (AJT) is the nominated officer for the school, ${ }^{2}$ to whom medical students should come if they have concerns relating to HIV. She is responsible for advising the occupational health department and the clinical advisers on the prevalence of bloodborne viruses worldwide, on reducing the risk of exposure, and on management after exposure.

A document summarising the school's policy on bloodborne viruses, including the education and training of students in avoiding exposure, was produced in 1991 and has recently been updated. The importance of guidance for students, not only on their electives, was emphasised by results of the recent Public Health Laboratory Service survey, which showed a high prevalence $(15-20 \%)$ of markers of current or past infection with hepatitis $\mathrm{B}$ in patients attending our trust (E Miller, personal communication). Anonymous screening of antenatal serum samples has shown that our patients also have a relatively high prevalence of HIV infection $(0.3-0.5 \%)^{3}$

Each year the occupational health department in conjunction with the department of virology circulates a document to all students with specific advice relating to the risks of acquiring bloodborne viruses while on elective, how to minimise this risk, and what to do if exposed. Prompt reporting and appropriate follow up is emphasised. Since health departments in the United Kingdom now recommend prophylaxis after exposure to $\mathrm{HIV}^{4}$ students visiting developing countries that have a relatively high prevalence of HIV infection are advised to take with them a six day course of zidovudine, which costs about $£ 40$. This allows them to start treatment within an hour of exposure, as recommended, and provides time to seek advice. Monotherapy is regarded as adequate in countries where anti-retroviral drugs are not routinely prescribed. Our guidelines emphasise that the school does not permit students travelling to areas with high prevalence of HIV infection to undertake an obstetrics and gynaecology attachment and that surgery is only permitted in hospitals with high standards of supervision and infection control. All elective proposals and the risks of infection with bloodborne viruses should be discussed with clinical advisers.

We summarise final year students' perception of the advice provided relating to bloodborne virus infections and their experiences during their electives.

\section{Methods}

An anonymous questionnaire was sent to 220 final year medical students after they completed their electives. A second wave was sent a few weeks later to all students to maximise the response rate. The questionnaire (see website) was designed to seek information on the risks of exposure to and protection against infection with bloodborne viruses, particularly during the elective period.

For the purposes of providing advice to elective students, data from the WHO, UNAIDS, and the Public Health Laboratory Service Communicable Disease Surveillance Centre ${ }^{5-8}$ were used to define areas where HIV infection is relatively prevalent-namely, subSaharan Africa (most recent estimate of prevalence of HIV up to $40 \%{ }^{9}$ ); Central America, the Caribbean, and 
South America (up to $6 \%{ }^{9}$ ), and South East Asia and the Indian subcontinent (up to $2.4 \%{ }^{9}$ ). Within these broad areas and within countries themselves, prevalence varies considerably; in some areas, it is increasing rapidly. Furthermore, these figures may underestimate the prevalence of HIV in hospital patients. These areas also have a relatively high prevalence of hepatitis $\mathrm{B}$ and hepatitis C. ${ }^{10}{ }^{11}$

\section{Results}

All of the $148 \quad(67 \%)$ students who returned questionnaires had been vaccinated against hepatitis B; $134(91 \%)$ had developed an adequate response (>100 mIU/ml). Most students thought that they had received adequate training in phlebotomy $(120 ; 81 \%)$ and infection control for bloodborne viruses (106; $72 \%$ ) during their clinical training.

Sixty five of the 148 students (44\%) visited areas with a relatively high prevalence of HIV infection (figure). Thirty eight students were aware of this, and of these, $24(63 \%)$ visited sub-Saharan Africa, 8 (21\%) South East Asia or the Indian subcontinent, and 6 $(16 \%)$ Central America, the Caribbean, or South America. All but one of the 38 students had discussed their elective with their clinical adviser or the occupational health department, or both, but only 25 $(66 \%)$ had specifically discussed the risks of acquiring bloodborne viruses. Eighteen (47\%) of the 38 attachments included surgery, trauma, or obstetrics and gynaecology; 16 of these students thought that they had been well supervised. Despite the school's policy, two students had obstetrics and gynaecology attachments in areas of Africa with a particularly high prevalence of HIV infection (Zimbabwe and Uganda/ Sudan). Both students had discussed their elective with the occupational health department and their clinical adviser, but neither the students nor their clinical advisers had considered the issue of bloodborne viruses. Both of these students thought that they had been well supervised during their attachments.

Twenty seven of the $65(42 \%)$ students who visited areas with a relatively high prevalence of HIV infection were unaware of this; 24 of these $(89 \%)$ visited South East Asia or the Indian subcontinent and $3(11 \%)$ Central America, the Caribbean, and South America. All but two had discussed their elective with their clinical adviser or the occupational health department. Only 6

Table 1 Preparation for and experiences during elective periods in areas with relatively high prevalence of HIV infection. Values are numbers (percentages) of students

\begin{tabular}{lcc} 
& $\begin{array}{c}\text { Student's awareness of high prevalence } \\
\text { of HIV infection in area }\end{array}$ \\
\cline { 2 - 3 } & Aware ( $\mathbf{n = 3 8 )}$ & Not aware (n=27) \\
\hline Preparation for elective & $13(34)$ & 0 \\
\hline Purchasing zidovudine & $24(63)$ & $8(30)$ \\
\hline Purchasing a medi-kit & $20(53)$ & $4(15)$ \\
\hline Purchasing latex gloves & $9(24)$ & $3(11)$ \\
\hline Obtaining dental check up & & \\
\hline During elective & $20(53)$ & $19(70)$ \\
\hline $\begin{array}{l}\text { Good standards of infection control } \\
\text { for bloodborne viruses found }\end{array}$ & $29(76)$ & $19(70)$ \\
\hline $\begin{array}{l}\text { Gloves readily available locally } \\
\text { Sharps boxes readily available locally }\end{array}$ & $27(71)$ & $20(74)$ \\
\hline \begin{tabular}{l} 
Well supervised during elective \\
\hline
\end{tabular} & $27(71)$ & $19(70)$ \\
\hline
\end{tabular}

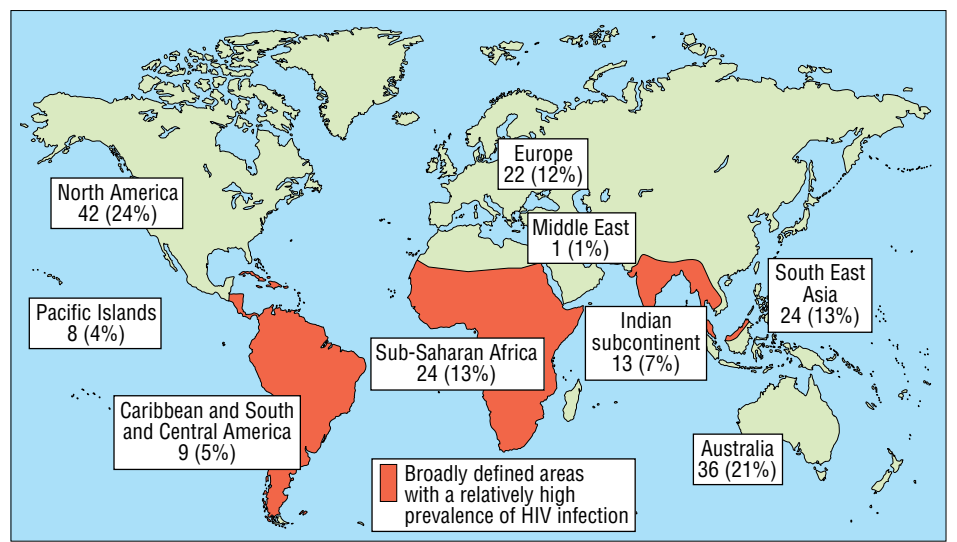

Number of visits by medical students to different parts of the world during their electives. Some of the 148 students surveyed visited more than one area

Table 2 Percutaneous or mucosal exposures to blood or other body fluids during student's elective period

\begin{tabular}{llccccc}
$\begin{array}{l}\text { Medical } \\
\text { student }\end{array}$ & $\begin{array}{l}\text { Country } \\
\text { visited }\end{array}$ & $\begin{array}{c}\text { Estimated } \\
\text { prevalence } \\
(\%) \text { of HIV } \\
\text { in adults }\end{array}$ & $\begin{array}{c}\text { First aid } \\
\text { applied } \\
\text { immediately }\end{array}$ & $\begin{array}{c}\text { Incident } \\
\text { reported }\end{array}$ & $\begin{array}{c}\text { HIV status } \\
\text { of patient } \\
\text { known }\end{array}$ & $\begin{array}{c}\text { Zidovudine } \\
\text { taken after } \\
\text { exposure }\end{array}$ \\
\hline 1 & South Africa & 13 & Yes & Yes & Yes & Yes \\
\hline 2 & Nigeria & 4 & Yes & No & Yes & No \\
\hline 3 & Sri Lanka & 0.1 & Yes & No & No & No \\
\hline 4 & Kenya & 12 & Yes & No & No & No \\
\hline
\end{tabular}

(22\%) had specifically discussed the risk of acquiring bloodborne viruses. Seven students $(26 \%)$ had studied surgery and thought that they were well supervised. None had studied trauma or obstetrics and gynaecology.

None of the 27 students visiting areas that were not perceived to have a high prevalence of HIV infection took zidovudine with them, and relatively few took a medi-kit $(8 ; 30 \%)$ or latex gloves $(4 ; 15 \%) ; 19(70 \%)$ found good standards of infection control for bloodborne viruses and $19(70 \%)$ thought that they were well supervised (table 1). Only 13 of the 38 students (34\%) who knew that the areas they were visiting had a relatively high prevalence of HIV infection took zidovudine, $24(63 \%)$ took a medi-kit and 20 $(53 \%)$ gloves; only $20(53 \%)$ found good standards of infection control for bloodborne viruses but 27 (71\%) thought that they were well supervised.

Three of the four students with percutaneous or mucosal exposures to blood or other body fluids while on elective were in areas of relatively high HIV endemicity. Only one reported the incident (table 2). It is unclear from the questionnaire whether the student visiting South Africa received an exposure from an HIV positive patient and if the course of zidovudine was completed. Forty four of the 148 respondents $(30 \%)$ had received at least one such exposure during the rest of their clinical training and $33(75 \%)$ had not reported these.

\section{Discussion}

\section{Perceptions of risks from HIV on elective}

Although the students and the clinical advisers had been provided with literature indicating areas that had a relatively high prevalence of HIV infection, almost a fifth of respondents $(27 / 148)$ visited countries with a high prevalence without being aware of this; all but two students had discussed their elective with their clinical 
adviser or the occupational health department. All 27 visited areas other than sub-Saharan Africa. It is insufficiently appreciated not only by students but also by some of those advising them that there has been a substantial rise in the prevalence of HIV infection in parts of South East Asia and the Indian subcontinent, South and Central America, and the Caribbean. About 25\% of people with HIV infection live in these areas, and India is the country with the highest number of people infected with HIV. ${ }^{5}$ Data on the worldwide prevalence of $\mathrm{HIV}$ is now more widely available. ${ }^{912-14}$

\section{Risks from and protection against bloodborne viruses}

Students voluntarily contributed details about conditions they faced on elective. Infection control procedures were sometimes poor, boxes for depositing "sharps" being unavailable or, when present, overflowing. One student described how there was sometimes no water in an African hospital and elective operations had to be performed without scrubbing. One student who visited India said that needles were frequently left lying around.

Zidovudine was purchased by only a small proportion (34\%) of students visiting areas which they knew to have a high prevalence of HIV. This may relate to cost: two students voluntarily stated that they felt that the expense (about $£ 40$ ) was too high. To encourage compliance, medical schools should consider bearing the cost.

Unlike some medical schools, ours allows medical students to go on electives in countries in which HIV and other bloodborne viruses are endemic. Although they were officially restricted from obstetric practice, two students, or those advising them, seemed to be unaware of this advice, or disregarded it. For example, one student carried out an obstetrics and gynaecology attachment in Zimbabwe-yet the prevalence of HIV in pregnant women in Harare has recently been reported to be $32 \% .^{13}$

\section{Training in phlebotomy and infection control}

A high proportion of students felt that their training in phlebotomy and infection control in the earlier part of their clinical course had been adequate. This is of importance since there is a relatively high prevalence of bloodborne viruses in inner city areas in Britain, particularly London. This view, however, was not borne out by our findings. Previous surveys of medical students have confirmed that, from the beginning of their clinical training, they are at risk of infection with bloodborne viruses. ${ }^{15}$ About a third of respondents in our survey admitted to at least one percutaneous or mucosal exposure to potentially infectious body fluids, four while on their elective. It is of concern that three quarters of students had not reported their exposures and consequently did not have the benefit of treatment or follow up.

\section{Recommendations}

Our survey emphasises the need for firmer measures to ensure that students have the best possible protection. All medical schools should produce and regularly update guidelines regarding protection from bloodborne viruses during clinical studies, including electives; education and training in infection control should start at the earliest opportunity.
- During their elective, two fifths of 65 medical students who visited areas with a high prevalence of HIV infection were unaware of this; these areas were outside sub-Saharan Africa

- These students, and some of their advisers, were apparently unaware of the increasing prevalence of HIV infection in South East Asia and the Indian subcontinent and in Central America, the Caribbean, and South America. Consequently, they did not follow the medical school's advice regarding preparation for electives in areas with a high prevalence of HIV infection

- Three of the four students who had experienced a percutaneous or mucosal exposure to potentially infectious body fluids while on elective were working in areas with a high prevalence of HIV infection; $30 \%$ of students had had at least one such exposure during the remainder of their clinical training

- Although most students believed that they had had adequate training in phlebotomy and infection control, $75 \%$ failed to report exposures to potentially infectious body fluids

- All medical schools should produce and regularly update guidelines regarding protection from bloodborne viruses during clinical studies, including electives; education and training in infection control should start at the earliest opportunity

Contributors: CG helped design the questionnaire and analyse data; AT instigated and supervised the study; JB helped CG and AT write the paper and has overall responsibility for UMDS recommendations on bloodborne virus infections. JR is guarantor of this paper.

Funding: None.

Competing interests: None declared.

1 Banatvala N, Doyal L. Knowing when to say "no" on the student elective. studentBMJ 1997;5:354-5.

2 UK Health Departments. AIDS/HIV-infected health care workers: guidance on the management of infected health care workers. Recommendations of the Expert Advisory Group on AIDS. London: Department of Health, 1994.

3 Banatvala JE, Chrystie IL, Palmer SJ, Sumner D, Kennedy J, Kenney A. HIV screening in pregnancy. Lancet 1991;337:1218.

4 UK Health Departments. Guidelines on Post-exposure prophylaxis for Health Care Workers Occupationally Exposed to HIV London: Department of Health, 1997.

5 Public Health Laboratory Service. AIDS and HIV infection worldwide. CDR 1997;7:461-2.

6 World Health Organisation. Global AIDS surveillance. Wkly Epidemiol Rec 1998;73:193-4.

7 World Health Organisation. Global AIDS surveillance Part II. Wkly Epidemiol Rec 1997;72:365-8.

8 Bernard RP, Zellweger U, Wang J, Somaini B. A global view of HIV infection. Geneva: UNAIDS, 1997.

9 UNAIDS/WHO. Report on the global HIV/AIDS epidemic. Geneva: UNAIDS/WHO, 1998.

10 World Health Organization. Hepatitis C: global prevalence. Wkly Epidemiol Rec 1997;72:341-8.

11 Gust ID. Comparison of the epidemiology of Hepatitis A and B. In: Szmuness D, Alter HJ, Maynard JE, eds. Proceedings of the Third International Symposium on Viral Hepatitis, New York City, March 30 - April 2, 1981. Philadelphia: The Franklin Institute Press, 1982.

12 Balter M. HIV Incidence: 'more serious than we imagined.' Science 1998;280:1864.

13 Gottlieb S. Gap in HIV infection widens. BMJ 1998;317:11.

14 Public Health Laboratory Service. The global HIV epidemic. CDR 1998;8:227.

15 Tereskerz PM, Pearson RD, Jagger J. Occupational exposure to blood among medical students. N Engl J Med 1996;335:1150-3.

(Accepted 23 October 1998) 